\title{
TORCH screening used appropriately in China?-three years results from a teaching hospital in northwest China
}

\author{
Lin-Chuan Wang ${ }^{1 \dagger}$, Fang Yan $^{2 \dagger}$, Jing-Xiong Ruan ${ }^{1}$, Yao Xiao ${ }^{1}$ and Yan $\mathrm{Yu}^{3^{*}}$
}

\begin{abstract}
Objectives: TORCH infections caused by Toxoplasma gondii (TOX), rubella virus (RV), cytomegalovirus (CMV) and herpes simplex virus 1,2 (HSV-1,2) are associated with congenital anomalies. The study aimed to analyze the characteristics of TORCH screening in reproductive age women.

Methods: A total of 18,104 women (2015-2017) from a teaching hospital in Xi'an, China, were enrolled in the study. The characteristics of TORCH screening, i.e., the application of TORCH test, the seroprevalence, the impact of age, periods of gestation and woman with bad obstetric history $(\mathrm{BOH})$ on the serological data were investigated.

Results: In the study, 319 women (1.76\%) performed dynamic TORCH test. 51.66, 20.44 and 3.83\% of the population did the test in the pre-gestation period, the first and third trimester, respectively. Quite a few pregestation women (29.74\%) ignored screening of IgG antibodies. The overall IgG/lgM seropositvity of TOX, RV, CMV, HSV-1 and HSV-2 was 4.35\%/0.35, 90\%/0.63, 96.79\%/0.97, 81.11\%/0.14 and 6.1\%/0.19\%, respectively. The age-specific distributions and periods of gestation had no significant effect on the seroprevalence of TORCH agents, $p>0.05$. However, BOH was significantly associated with higher seropositvity of IgM (RV, CMV, HSV-1 and HSV-2) and IgG (CMV and HSV-1) antibodies, $p<0.05$.
\end{abstract}

Conclusion: In Xi'an region, more attentions should be paid to TOX, CMV, HSV-2 and the women with BOH for TORCH screening. Meanwhile, a greater emphasis needs to be placed on TORCH test used inappropriately in China.

Keywords: Toxoplasma gondii, Rubella virus, Cytomegalovirus, Herpes simplex virus

\section{Introduction}

TORCH infections, which also called perinatal or congenital infections, are caused by serial organisms during pregnancy with an acronym $\mathrm{TORCH}$, which named Toxoplasma gondii (TOX), Other (hepatitis viruses, parvovirus, human immunodeficiency virus, EpsteinBarr virus, syphilis), Rubella virus (RV), Cytomegalovirus (CMV), and Herpes Simplex Virus (HSV) [1-3]. The diagnosis and management of other TORCH infections, i.e., hepatitis viruses, syphilis and human immunodeficiency virus, are clear and highly efficacious. However, most of the TORCH infections, such as TOX, RV, CMV and HSV, which are easily overlooked and difficult to

\footnotetext{
* Correspondence: yu.yan74@163.com

'Linchuan Wang and Fang Yan contributed equally to this work.

${ }^{3}$ Honghui Hospital, Xi'an Jiaotong University, Xi'an, Shaanxi Province, China

Full list of author information is available at the end of the article
}

diagnose due to be often asymptomatic and relatively low virulence, may lead to serious fetal consequences, i.e., abortions, intrauterine foetal deaths, congenital malformations [4-6]. Therefore, early recognition these TORCH infections are important for treatment and prevention strategies to avoid adverse fetal outcomes.

Up to present, only CMV and HSV-2 PCR tests were approved for clinical practice by the China Food and Drug Administration (CFDA). Therefore, the serological evidences through detection of IgM and IgG antibodies against TORCH agents are the preferred approaches for identification of these infections in China. The present study was carried out to investigate the application and epidemiological characteristics of TOX, RV, CMV and HSV screening in reproductive age women from Xi'an region, China.

(c) The Author(s). 2019 Open Access This article is distributed under the terms of the Creative Commons Attribution 4.0 International License (http://creativecommons.org/licenses/by/4.0/), which permits unrestricted use, distribution, and reproduction in any medium, provided you give appropriate credit to the original author(s) and the source, provide a link to the Creative Commons license, and indicate if changes were made. The Creative Commons Public Domain Dedication waiver (http://creativecommons.org/publicdomain/zero/1.0/) applies to the data made available in this article, unless otherwise stated. 


\section{Materials and methods}

\section{Study population}

The retrospective study was conducted from January 2015 to December 2017 at the First Affiliated Hospital of Xi'an Jiaotong University. A total of 18,104 reproductive age women with TORCH screening were included. The median age was 29 years (range: $20-44$ years). Patients with bad obstetric history $(\mathrm{BOH})$ in the study were those with history of previous unfavourable foetal outcome in terms of two or more abortions, infertility, intrauterine growth retardation, intrauterine foetal death, still birth, early neonatal death and congenital anomalies. The data used in the study were obtained from the Laboratory Information System (LIS) of the First Affiliated Hospital of Xi'an Jiaotong University.

\section{Laboratory tests}

IgM and IgG antibodies of TORCH agents detection

The Enzyme-Linked Immunosorbent Assay (ELISA) and Chemiluminesent Micropaticle Immuno Assay (CMIA) were applied to IgM and IgG antibodies detection for TORCH agents before and after 2017, respectively. The commercial ELISA and CMIA kits (Autobio Diagnostics
Co., Ltd., Zhengzhou, China) were based on two principles, i.e., the indirect principle for IgG antibody (Fig. 1a) and capture principle for IgM antibody (Fig. 1b). The sera were tested using the Addcare Asp 150/8 analyzor (Addcare Bio-Tech Co., Ltd., Yantai, China) for ELISA and Autolumo A2000 analyzor (Autobio Diagnostics Co., Ltd., Zhengzhou, China) for CMIA according to the manufacturer's instructions and interpretations.

\section{PCR test}

Quantification of CMV-DNA and HSV-2-DNA was performed on the DA7600 RealTime amplification fluorescence detection System (DaAn Gene Co., Ltd., ZhongShan, China) using specific primers. The boiling method $\left(100^{\circ} \mathrm{C}\right.$ for $\left.10 \mathrm{~min}\right)$ was used to extract DNA. The PCR parameter was: Pre-denaturation at $93^{\circ} \mathrm{C}$ for 2 min, then $93^{\circ} \mathrm{C}$ for $45 \mathrm{~s} \rightarrow 55^{\circ} \mathrm{C}$ for $60 \mathrm{~s} \rightarrow 10$ cycles; $93^{\circ} \mathrm{C}$ for $30 \mathrm{~s} \rightarrow 55^{\circ} \mathrm{C}$ for $45 \mathrm{~s} \rightarrow 30$ cycles. The lower limit of detection is approximately 50 copies $/ \mathrm{mL}$.

\section{Statistical analysis}

Statistical analyses were performed by SPSS13.0 (serial number 5026743; SPSS Inc., Chicago, Illinois, USA).

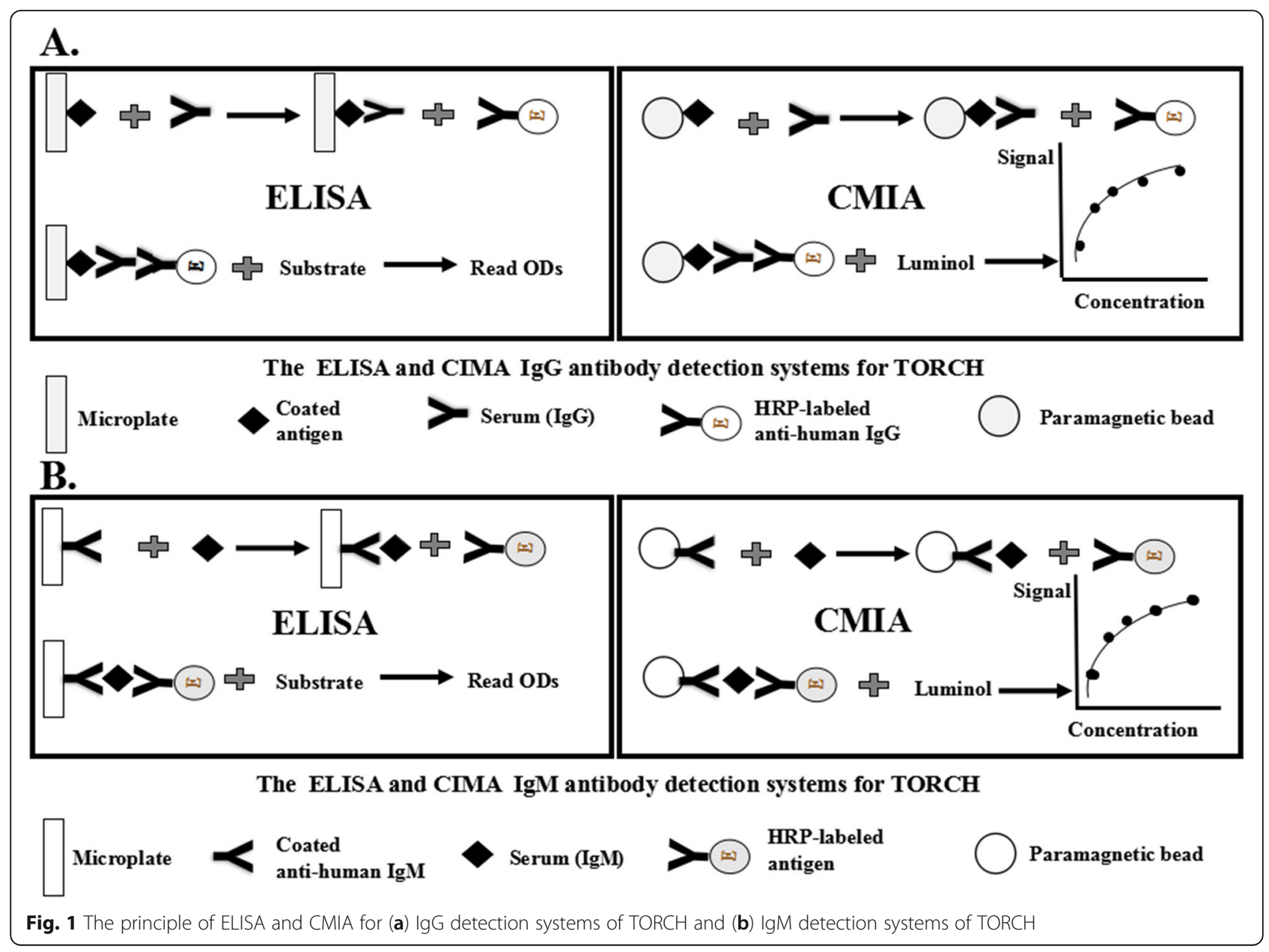


Categorical variables were compared using the Fisher exact test. A $p$-value $<0.05$ was considered to be statistically significant.

\section{Results}

The epidemiological characteristics and application of TORCH test

During the study period, 18,104 reproductive age women (20-44 years) were included. The test numbers in 2015, 2016 and 2017 were 4953, 6387 and 6764, respectively. The agespecific distributions of the population were $14.69 \%$ for 20 25 years, $53.88 \%$ for $26-30$ years and $31.43 \%$ for $\geq 31$ years. The habitual abortion, infertility and spontaneous abortion accounted for the majority of the women with bad obstetric history (BOH) (56.89, 27.77 and $12.46 \%$, respectively).

In the study, 51.66, 20.44, 24.08 and $3.83 \%$ of the women performed TORCH screening in the pregestation period, the first, second and third trimester, respectively. The woman attached importance to both IgM and IgG antibodies of TORCH agents in the first and second trimester, with a proportion of 89.11 and $80.06 \%$. However, less than half of the women in the third trimester (44.30\%) and with $\mathrm{BOH}(40.74 \%)$ tested both IgM and IgG antibodies. Meanwhile, $29.74 \%$ of the pregestation women and $18.94 \%$ of pregnant women only screened IgM antibody. With age increased, the attention to IgG antibody test decreased, Table 1.

\section{Prevalence of anti-TORCH agents}

In our study, the overall seropositvity of TOX, RV, CMV, HSV-1 and HSV-2 was 4.34, 90, 96.79, 81.11 and
$6.1 \%$ for IgG antibodies whereas it was only $0.35,0.63$, $0.97,0.14$ and $0.85 \%$ for IgM antibodies, respectively. In contrast to 2015 and 2016 (ELISA), the IgG seropositvity for TOX, RV, HSV-1 significant decrease and the IgM seropositvity for TOX, RV and HSV-2 significant increase were observed in 2017 (CMIA), $p<0.05$. The age-specific distributions and periods of gestation had no significant effect on the seropositvity of TORCH agents, $p>0.05$. However, the seropositvity of IgG antibodies (CMV and HSV-1, Fig. 2a) and IgM (RV, CMV, HSV-1 and HSV-2, Fig. 2b) in $\mathrm{BOH}$ group were significantly higher than that in normal control group, $p<0.05$, Table 2 .

\section{Results of serial serologic tests and PCR}

In the study, 319 women (1.76\%) performed two or more times serologic tests. Among 29 cases who were seropositive to only IgM antibody in the first screening, 6 cases had IgG antibody seroconversion (1 for TOX and 5 for $\mathrm{CMV}$ ). The persistence and disappearance of IgM antibody was found in 20 and 3 cases, respectively. Additionally, 64 women performed both serological and PCR tests for CMV $(n=59)$ and HSV-2 $(n=5)$, Table 1. It was noteworthy that 15 cases who were only seropositive to IgG antibody were identified as CMV infection because the IgG antibody level sharply increased in sequential serum samples, and 8 cases were also positive to CMV-DNA test. 10 and 3 of the 12 CMV infections confirmed by PCR were seropositive to IgG and IgM antibodies, respectively. Meanwhile, 45 and 4 of the 47 women with CMV-DNA negative result were also seropositive to IgG and IgM antibodies, respectively. One

Table 1 The epidemiological characteristics and application of TORCH test

\begin{tabular}{|c|c|c|c|c|c|}
\hline \multirow[t]{2}{*}{ Characteristics } & \multirow[t]{2}{*}{ No } & \multicolumn{2}{|l|}{ Application of TORCH test } & \multirow[t]{2}{*}{ Others Characteristics } & \multirow[t]{2}{*}{ No } \\
\hline & & Both IgM and lgG: n(\%) & Only lgM: $\mathrm{n}$ & & \\
\hline Year & & & & The Distributions of $\mathrm{BOH}$ & \\
\hline 2015 & 4953 & 4937 (99.68) & 16 & Infertility & 760 \\
\hline 2016 & 6387 & $4030(63.10)$ & 2357 & Intrauterine foetal death & 37 \\
\hline 2017 & 6764 & $4699(69.47)$ & 2065 & Intrauterine growth retardaion & 7 \\
\hline Age & & & & Still birth & 18 \\
\hline 20 25 years & 2659 & $2082(78.30)$ & 577 & Habitual abortion & 1557 \\
\hline $26 \sim 30$ years & 9755 & $7438(76.25)$ & 2317 & Spontaneous abortion & 341 \\
\hline$\geq 31$ years & 5690 & $4146(72.86)$ & 1544 & Missed abortion & 4 \\
\hline Before pregnancy & 9352 & $6571(70.26)$ & 2781 & Fetal congenital malformation & 13 \\
\hline Periods of gestation & 8752 & $7094(81.06)$ & 1658 & Serologic test & \\
\hline First trimester & 3700 & $3297(89.11)$ & 403 & Only one time & 17,785 \\
\hline Second trimester & 4359 & $3490(80.06)$ & 869 & Two or more times $\boldsymbol{\Lambda}$ & 319 \\
\hline Third trimester & 693 & $307(44.30)$ & 386 & PCR test & \\
\hline $\mathrm{BOH}$ group & 2737 & $1115(40.74)$ & 1622 & CMV-DNA test ${ }^{a}$ & 59 \\
\hline Normal control group & 15,367 & 12,599 (81.99) & 2768 & HSV-2-DNA test ${ }^{b}$ & 5 \\
\hline
\end{tabular}

Note: $\boldsymbol{\Delta}$ In the first serologic test, 29 cases were seropositive to only lgM antibody (4 for TOX, 2 for RV, 17 for CMV, 2 for HSV-1 and 4 for HSV-2); ${ }^{a} 45$ were serum, 14 were urine; ${ }^{\mathrm{b}} 1$ was serum and 4 were secretion 

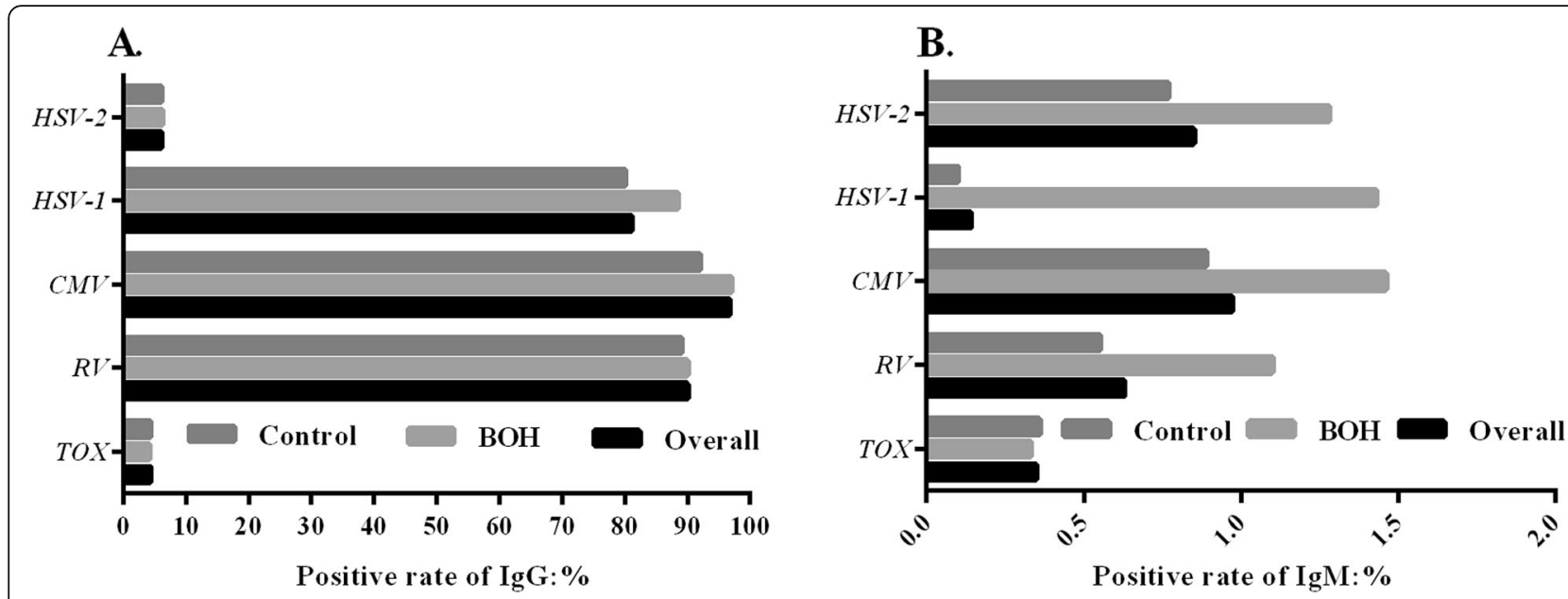

Fig. 2 The positive rates of antibodies against TOX, RV, CMV, HSV-1 and HSV-2 in BOH group, normal control group and overall population. a lgG; b $\lg M$

HSV-2 infection confirmed by PCR was seropositive to only IgM antibody. Among the 4 PCR negative women for HSV-2, however, seropositive result (IgG antibody) was observed in only one case, Table 3.

\section{Discussion}

The immune status and susceptible populations for TORCH pathogens should be evaluated by antepartum screening [7-9]. During the pregnancy, the TORCH infections at different status, i.e., primary infection of TOX, primary or recurrent infections of CMV, and primary infections at the first trimester for RV and at the third trimester for HSV, determine the risk of vertical transmission and severity of fetal $[4,5,10]$. However, the diagnosis of primary and recurrent $\mathrm{TORCH}$ infections by serological assay rely on a series of tests, such as the dynamic tests for both IgM and IgG antibodies to observe the seroconversion and change of IgG level, and an avidity test for the positive to IgG antibody [10, 11]. In this respect, TORCH screening should be started at right time (pre-gestation period, the first and third trimester), and not be considered as a single serum test. During the study period, more women in 2016 and 2017 than in 2015 performed TORCH screening due to the implementation of "two-child policy" in China since 1 Jan 2016 [12]. However, only $1.76 \%$ of the women performed dynamic TORCH tests and quite a few pregestation women $(29.74 \%)$ ignored the screening test for IgG antibody in the study.

In the study, the seroprevalence of TORCH agents was significantly associated with $\mathrm{BOH}$, but it was not effected by the age-specific distributions and periods of gestation. This was similar with other previous studies [13, 14]. RV, CMV and HSV-1 accounted for the majority of the TORCH infections with seropositivity of $90,96.79$ and
81.11\% for IgG antibodies, however, the incidence of primary and acute TORCH infections was very low with seropositivity of $0.14-0.97 \%$ for IgM antibody. The findings are similar with previously published studies both in local [15] and elsewhere [16-18]. Owing to rarely eat raw meat in China, the seropositivity of IgG antibody for TOX in our study was lower than that in Turkey (31\%) [16], India (28\%) [17] and Canada (59.8\%) [18]. In our study, the overall seropositvity of TOX, RV, CMV, HSV1 and HSV-2 was 4.34, 90, 96.79, 81.11 and $6.1 \%$ for IgG antibodies. That implied only 4.34 and $6.10 \%$ of the child-bearing age women were immune to TOX and HSV-2 compared with $90 \%$ for RV, $96.79 \%$ for CMV and 81.11\% for HSV-1.

The IgM antibody can be detected in different clinical situations, i.e., the primary $\mathrm{TORCH}$ infections, the persistence of IgM and the false positive due to Rheumatoid factor (RF) [10], Epstein-Barr (EB) virus [19] or antiphospholipid syndrome [20]. In the present study, among the 29 cases who were positive to IgM but negative to IgG antibodies in the first TORCH test, 6 cases had IgG seroconversion. In addition, of the $12 \mathrm{CMV}$ infections and 47 CMV non-infections by PCR assay, the IgM antibody was detected in 2 and 4 cases, respectively. However, the negative to IgM antibody was observed in 15 CMV infections with dynamic increase for IgG level. The findings also demonstrate the opinion that the IgM result of a single serologic test is difficult and inconclusive to the diagnosis of TORCH infections $[5,21,22]$.

\section{Conclusions}

In summary, more attentions should be paid to TOX, CMV, HSV-2 and the women with $\mathrm{BOH}$ for TORCH screening in Xi'an region. Meanwhile, a greater emphasis needs to be placed on TORCH test used 


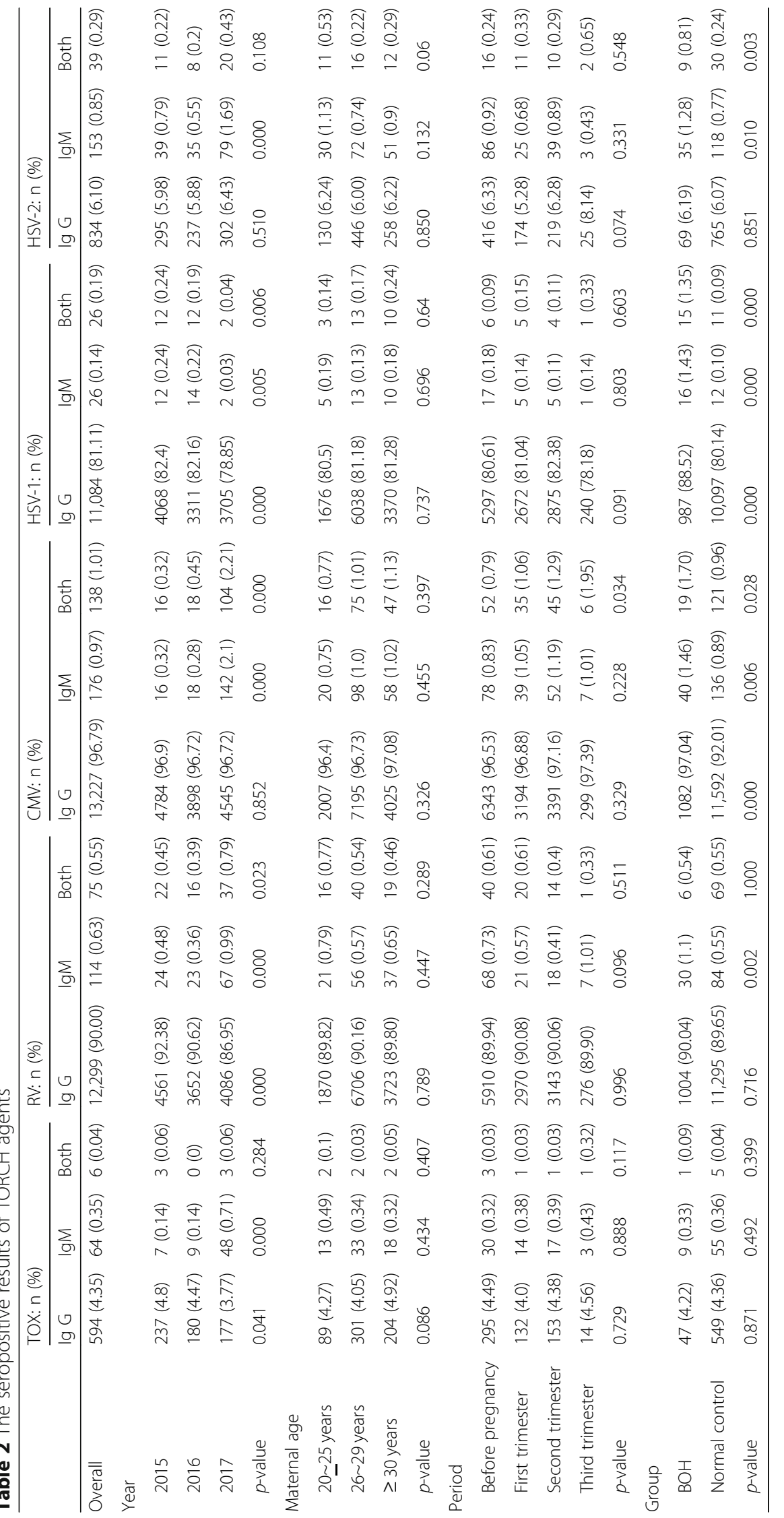


Table 3 The serological results of CMV and HSV-2 for women with PCR test

\begin{tabular}{lllll}
\hline $\begin{array}{l}\text { Serologic } \\
\text { results }\end{array}$ & \multicolumn{2}{l}{ Quantification of CMV-DNA } & Quantification of HSV-2-DNA \\
\cline { 2 - 3 } \cline { 2 - 4 } & Positive $(n=12)$ & Negative $(n=47)$ & 0 & Positive $(n=1)$ \\
\hline $\lg M-\lg G-$ & 0 & 0 & 1 & 0 \\
$\lg M+\lg G-$ & 2 & 2 & 0 & 1 \\
$\lg M-\lg G+$ & 9 & 43 & 0 & 0 \\
$\lg M+\lg G+$ & 1 & 2 & 0 & 0 \\
\hline
\end{tabular}

inappropriately in China, i.e., generally considered to be a single serum test, ignore the evaluation of pregestation immune status and dynamic monitoring of IgG antibody. For diagnosis of TORCH infection, the results of serial serologic tests, PCR and clinical manifestations should be taken into account.

\section{Abbreviations}

BOH: Bad obstetric history; CFDA: China Food and Drug Administration; CMIA: Chemiluminesent Micropaticle Immuno Assay; CMV: Cytomegalovirus; EB: Epstein-Barr; HSV: Herpes simplex virus; LIS: Laboratory Information System; RF: Rheumatoid factor; RV: Rubella virus; TOX: Toxoplasma gondii

\section{Acknowledgments}

None.

\section{Authors' contributions}

$L W, F Y$ and $Y Y$ were major contributors in the design and interpretation of the study. The original draft was written by LW, and submitted \& substantively revised by YY. FY, JXR and YX were responsible for the data collection. The statistical analysis and figure of the study were performed by LW. All authors have read and approved the manuscript, and ensure that this is the case.

\section{Funding}

The design of the study, collection and interpretation of data were conducted by the project team members of Natural Science Basic Research Program of Shaanxi Province, China (No. 2019JM-364).

\section{Availability of data and materials}

The data used in the study was permitted to be obtained from LIS by the Clinical Laboratory of the First Affiliated Hospital of Xi'an Jiaotong University. All patient information was conducted anonymously in the study.

\section{Ethics approval and consent to participate}

Due to the retrospective nature and all patient's information was kept confidential, the study was deemed exempt from review and approved to be not require informed consent by the Institutional Review Board of the First Affiliated Hospital of Xi'an Jiaotong University.

\section{Consent for publication}

Not applicable.

\section{Competing interests}

The authors declare that they have no competing interests.

\section{Author details}

${ }^{1}$ The First Affiliated Hospital of Xi'an Jiaotong University, Xi'an, Shaanxi Province, China. ${ }^{2}$ Xi'an NO.3 Hospital, Xi'an, Shaanxi Province, China.

${ }^{3}$ Honghui Hospital, Xi'an Jiaotong University, Xi'an, Shaanxi Province, China.
Received: 8 July 2018 Accepted: 27 November 2019

Published online: 09 December 2019

\section{References}

1. Madrid L, Varo R, Sitoe A, Bassat Q. Congenital and perinatally-acquired infections in resource-constrained settings. Expert Rev Anti-Infect Ther. 2016; 14(9):845-61.

2. Stegmann BJ, Carey JC, TORCH Infections. Toxoplasmosis, other (syphilis, varicella-zoster, parvovirus B19), rubella, Cytomegalovirus (CMV), and herpes infections. Curr Womens Health Rep. 2002;2(4):253-8.

3. Neu N, Duchon J, Zachariah P. TORCH infections. Clin Perinatol. 2015;42(1):77-103.

4. Boyer SG, Boyer KM. Update on TORCH infections in the newborn infant. Newborn Infant Nurs Rev. 2004:4(1):70-80.

5. Jong EPD, Vossen ACTM, Walther FJ, Lopriore E. How to use... neonatal TORCH testing. Arch Dis Child Educ Pract Edit. 2013:98(3):93-8.

6. Kishore J, Misra R, Paisal A, Pradeep Y. Adverse reproductive outcome induced by parvovirus B19 and TORCH infections in women with high-risk pregnancy. J Infect Dev Ctries. 2011;5(12):868-73.

7. Dominguez A, Plans P, Espunes J, et al. Rubella immune status of indigenous and immigrant pregnant women in Catalonia, Spain. Eur J Public Health. 2007:17(6):560-4.

8. Poliquin $\mathrm{VYMH}$, Murphy $\mathrm{KE}$, et al. Antepartum screening for maternal infection and immune status: is it time to broaden our routine? J Obstet Gynaecol Can. 2015;37(12):1118-21.

9. Carlier YTC, Deloron P, et al. Congenital parasitic infections: a review. Acta Trop. 2012;121(2):55-70.

10. Revello MG, Gerna G. Diagnosis and management of human cytomegalovirus infection in the mother, fetus, and newborn infant. Clin Microbiol Rev. 2002;15(4):680-715.

11. Ursu RG, Costin D, lancu LS, et al. The clinical utility of TORCH testing of pregnant women from northeastern Romanian population: application of electrochemiluminiscence assay. E-Health Bioeng Conf. 2015. p. 1-4.

12. Zeng $Y$, Hesketh $T$. The effects of China's universal two-child policy. Lancet. 2016:388(10054):1930-8

13. Saxena N, Lal M, Mittal G, Priya P. Is screening of TORCH worthwhile in women with bad obstetric history: an observational study from Himalayan hospital? Int J Biol Med Res. 2015;6(3):5158-61.

14. Rasti S, Ghasemi FS, Abdoli A, Piroozmand A, Mousavi SGA, Fakhrie-Kashan Z. ToRCH "co-infections" are associated with increased risk of abortion in pregnant women. Congenital Anomalies. 2016;56(2):73-8.

15. Li Z, Yang C, Liu P, et al. Prevalence of serum antibodies to TORCH among women before pregnancy or in the early period of pregnancy in Beijing Clinica Chimica Acta. 2009:403(1-2):212-5

16. Numan O, Vural F, Aka N, Alpay M, Coskun AD. TORCH seroprevalence among patients attending obstetric Care Clinic of Haydarpasa Training and Research Hospital affiliated to association of Istanbul northern Anatolia public hospitals. North Clin Istanb. 2015;2(3):203-9.

17. Prasoona KR, Srinadh B, Sunitha T, Sujatha M, Deepika ML, Vijaya LB, Ramaiah A, Jyothy A. Seroprevalence and influence of Torch Infections in high risk pregnant women: a large study from South India. J Obstet Gynaecol India. 2015;65(5):301-9.

18. Messier V, Lévesque B, Proulx JF, Rochette L, Libman MD, Ward BJ, Serhir B, Couillard M, Ogden NH, Dewailly E. Seroprevalence of toxoplasma gondii among Nunavik Inuit (Canada). Zoonoses Public Health. 2009;56(4):188-97.

19. Miendje DY, Goubau P, Bodéus M. False-positive IgM antibody tests for cytomegalovirus in patients with acute Epstein-Barr virus infection. Eur Clin Microbiol Infect Dis. 2000;19(7):557-60. 
20. De SC, Tabacco S, Rizzo F, Perrone G, Garufi C, Botta A, Salvi S, Benedetti PP, Lanzone A. Association between false-positive TORCH and antiphospholipid antibodies in healthy pregnant women. Lupus. 2017;(4) 096120331774156.

21. Picone OGL, Senat M, et al. Cytomegalovirus non-primary infection during pregnancy. Can serology help with diagnosis? J Matern Fetal Neonatal Med. 2017:30(2):224-7.

22. Yuka T, Shigeru Y, Yoichiro Y, et al. Serological screening of immunoglobulin $M$ and immunoglobulin $\mathrm{G}$ during pregnancy for predicting congenital cytomegalovirus infection. BMC Pregnancy Childbirth. 2019;19:205.

\section{Publisher's Note}

Springer Nature remains neutral with regard to jurisdictional claims in published maps and institutional affiliations.

Ready to submit your research? Choose BMC and benefit from:

- fast, convenient online submission

- thorough peer review by experienced researchers in your field

- rapid publication on acceptance

- support for research data, including large and complex data types

- gold Open Access which fosters wider collaboration and increased citations

- maximum visibility for your research: over $100 \mathrm{M}$ website views per year

At $\mathrm{BMC}$, research is always in progress.

Learn more biomedcentral.com/submissions 